\title{
Authoritarianism and the Crisis of the Argentine Political Economy
}





\title{
Authoritarianism and the Crisis of the Argentine Political Economy
}

\author{
WILLIAM C. SMITH
}


Stanford University Press

Stanford, California

(C) 1989 by the Board of Trustees of the

Leland Stanford Junior University

Printed in the United States of America

CIP data are at the end of the book 
To María de Lourdes and

Gabriela Lucía 



\section{Acknowledgments}

THIS STUDY of the Argentine political economy is the product of a prolonged gestation period of research and reflection. I began the research for this book during two years spent in Buenos Aires in the mid-1970s. The first, dissertation version of this study was completed in July 1980. Two weeks later I arrived at the Federal University of Minas Gerais in Belo Horizonte, Brazil, planning to spend one year as a Fulbright professor. But Brazil was irresistible and I remained nearly five years. Although Argentina was still my first passion, fascination with things Argentine had to compete with learning Portuguese, teaching Latin American politics to Brazilian graduate students, and studying the history, culture, and politics of my new country. Not until late 1987, when I was resident in Miami, did I undertake the radical transformation of an unwieldy dissertation of nearly 800 pages into a book.

As usually happens with large projects stretching over many years, numerous friendships were formed and debts incurred. I gratefully acknowledge the support given by my professors at Stanford University. Particular gratitude goes to Richard Fagen, whose friendship, patience, and understanding as an adviser I value highly. I also thank Barry Ames (then a visiting scholar at Stanford's Bolívar House), who saved me from several egregious errors, and Charles Drekmeier, who never lost his good humor while plunging into the alien territory of Latin American politics. Frank Bonilla, my first adviser at Stanford, I thank for his example as an intellectual who combines exemplary scholarship with concern for the implications of research for the lives of people.

While in Argentina I received friendship and invaluable intellectual stimulation from many sources. To Marcelo Cavarozzi 
and Oscar Oszlak, colleagues at the Centro de Investigación en Administración Pública (CIAP) of the Torcuato Di Tella Institute and then at the Centro de Estudios de Estado y Sociedad (CEDES), I owe many intellectual debts which are only imperfectly recognized in this book's citations. Thanks are also due for welcoming me back to CEDES for briefer visits in 1983 and 1987. I am especially grateful to my amigos queridos Lila Felicitas Milutín, Ricardo Milutín, Luis Ros, Susana Canela, and Juan Noel Grau for sharing their insights into Argentine society, and I thank them for accepting my wife and me into their families. I reserve special esteem for the late Don Miguel Milutín, a patriot in the best tradition of Argentine democratic politics and a wonderful compañero de vino tinto.

Among these Argentine friends and colleagues Guillermo O'Donnell merits particular mention. I fondly remember our many stimulating discussions attempting to make sense out of the Argentine riddle. Because O'Donnell and I were both writing on the same general questions, we agreed to refrain from reading the other's text until both had been completed. I thank him for his very generous reference in his own book to the dissertation version of my study. After sending my own manuscript to Stanford Press, I finally had the pleasure of reading O'Donnell's book, and I concur with his judgment that despite the inevitable coincidences, the different emphases of our texts make them more complementary than overlapping.* His study of the 1966-73 period is clearly a major extension of his earlier pioneering and influential work on bureaucraticauthoritarianism.

While at Stanford, I was fortunate to establish enduring friendships with an extraordinary group of Brazilians, including Malori José Pompermayer, Edgar Pontes de Magalhães, Benício V. Schmidt, Evelina Dagnino, Glaura Vásquez de Miranda, and Isaura Belloni. During my Brazilian sojourn these friendships deepened and new ones were established with Eli Diniz, Bernardo Sorj, Aurea Dreifuss, Fabio Wanderley Reis, Celson José da Silva, Otávio Dulce, Vera Alice Cardoso, and many others.

* See O'Donnell's comments in Bureaucratic-Authoritarianism: Argentina, 1966-1973, in Comparative Perspective (Berkeley: University of California Press, 1988), p. xiii. 
The intellectual fervor and the impressive scholarship produced by the Brazilian academic community in the early 1980 os made a major impact on me. Although my dissertation remained unopened during these years, the time spent reading and debating questions of theory and history with my students and colleagues substantially changed my thinking about politics and the state in Argentina and Latin America. I feel these changes are reflected positively in this book.

My research and writing was generously supported early on by a Foreign Area Fellowship from the Social Science Research Council and the American Council of Learned Societies. The final writing was funded in part by a grant from the Corporate Affiliates Program at the University of Miami. I am grateful for their support. An early version of Chapter 9 appeared in Generals in Retreat: The Crisis of Military Rule in Latin America, edited by Philip O'Brien and Paul Cammack (Manchester, Eng.: Manchester University Press, 1985). Portions of Chapter 10 were published in Lost Promises: Debt, Austerity, and Development in Latin America, edited by William L. Canak (Boulder, Colo.: Westview Press, 1989).

I have received particularly valuable written comments on the entire manuscript from Steven E. Sanderson, Roberto Patricio Korzeniewicz, and Jeff Stark. Peter Ranis, Scott Mainwaring, and Lisa Fuentes also made useful criticisms of individual chapters. David Dye was an extremely demanding critic of the earlier incarnation. Peter J. Kahn, Associate Editor at Stanford Press, did a marvelous editorial job and I thank him for shepherding the manuscript to publication. I am grateful to all of them and relieve them of responsibility for remaining errors of fact or interpretation.

I dedicate this book to María de Lourdes Baeza, for her encouragement of my initial interest in Latin America and for opening new cultures that have enriched me tremendously, and to my daughter Gabriela Lucía Baeza-Smith, who is the wonderful product of our complex life together. 
